\title{
The Prospects for Russian Gas in the European Market within the Context of Changing Market Conditions, Regulatory Environment and the EU Policy
}

\author{
V. Kulagin, S. Melnikova, A. Galkina, E. Osipova, E. Kozina
}

\begin{abstract}
Viatcheslav Kulagin - Head, Centre for International Energy Market Studies, Energy Research Institute, Russian Academy of Sciences; Deputy Head, Centre for International Energy Market Studies, Institute of Energy, National Research Institute Higher School of Economics; 31 Nagornaya Street, 117186 Moscow, Russian Federation; E-mail: vakulagin@hse.ru
\end{abstract}

Svetlana Melnikova - Analyst, Centre for International Energy Market Studies, Energy Research Institute, Russian Academy of Sciences; Research Fellow, Institute of Energy, National Research Institute Higher School of Economics; 31 Nagornaya Street, 117186 Moscow, Russian Federation; E-mail: s.melnikova@inbox.ru

Anna Galkina - Research Fellow, Energy Research Institute, Russian Academy of Sciences; 31 Nagornaya Street, 117186 Moscow, Russian Federation; E-mail: annegalkina@gmail.com

Ekaterina Osipova - Research Engineer, Energy Research Institute, Russian Academy of Sciences; 31 Nagornaya Street, 117186 Moscow, Russian Federation; E-mail: OsipovaEkaterina91@yandex.ru

Elena Kozina - Research Fellow, Energy Research Institute, Russian Academy of Sciences; Research Fellow, Institute of Energy, National Research Institute Higher School of Economics; 31 Nagornaya Street, 117186 Moscow, Russian Federation; E-mail: zelenakoz@yandex.ru

This article presents the results of an integrated study of the current state of the natural gas market in Europe and its prospective development. It examines energy policy, demand, the competitive ability of gas suppliers and the dynamics of external supply. It focuses especially on the impact of the European Union's current and prospective gas market legislation, which, in effect, forms a radically different gas market architecture and changes the operating conditions for all gas suppliers, including Russia. In order to assess market stability, the article evaluates future changes in the European market using economic and mathematical optimization modelling as well as the influence of various external and internal factors on the market. It offers conclusions on the priority aspects of energy policy that apply to Russian gas exports to Europe.

Key words: European Union, Russia, gas, regulation, contracts, energy policy, export policy

\section{The Current Transformation of the European Gas Market}

Not long ago, leading research organizations predicted that natural gas would dominate the world energy balance. However, between 2010 and 2014 the situation in the European gas market was the exact opposite. Europe has become the only region in the world with sharply negative gas consumption, which fell by $23 \%$ in four years after peaking in 2010 at 598 billion cubic metres (bcm).

In Europe, natural gas consumption is relatively stable in the household sector and gradually declining in the manufacturing sector in response to the active implementation of energysaving measures. Other factors influencing the decline are the relocation of some energy-intensive manufacturing facilities out of the region and an increase in the use of electric power. Inter-fuel competition is most intense in the European power sector. It is this very sector that 
contributed most to the overall decline in gas demand in Europe from 2010 to 2014. In just a few years, the amount of natural gas consumed in generating electricity fell in most countries in the region: in Italy from $33.4 \mathrm{bcm}$ in 2008 to $16.8 \mathrm{bcm}$ in $2014(-49.7 \%)$, the United Kingdom from $24.8 \mathrm{bcm}$ to $14.2 \mathrm{bcm}(-42.7 \%)$, Spain from $16 \mathrm{bcm}$ to $4.4 \mathrm{bcm}(-72.5 \%){ }^{1}$

Natural gas, coal and new renewable energy sources are the main competing fuels in Europe. It is frequently stated that a "low carbon" energy sector is being developed in the region, which would replace coal-fired power generation with gas-fired generation. Despite these statements, the recent practice demonstrates the opposite.

As the share of gas-fired power plants in European electric power generation declined from 2005 to 2014 (from $21 \%$ to $16 \%$ ), coal power generation lost substantially smaller volumes (from $29 \%$ to $26 \%$ ), while new renewable power generation using wind and solar power increased from $2 \%$ to $10 \%$.

Renewable power generation has become the absolute priority in the European energy policy in the 21st century. In some European countries, renewable energy sources - primarily offshore wind plants - are gradually becoming comparable to gas-powered generation. Even given the stagnating European economy, renewable power generation (with the exception of hydro), with its uncertain competitive ability and subsidies of around $€ 51.1$ billion in 2013 alone, showed a 1.7-fold increase in the last five years [Council of European Energy Regulators (CEER), 2015]. Meanwhile, natural gas has become too expensive, despite its environmental advantages over coal and oil. It has lost more of its position than all other energy resources. The European Union Emissions Trading System - the only economic instrument intended to limit the consumption of environmentally unclean coal, despite being cheaper than natural gas does not perform well and requires serious reform. However, proposed measures (including "back-loading" 900 million quotas and creating a market reserve) could improve the market but only after 2020. As such, climate considerations in the European context will take second place until then.

Major regulatory changes now are taking place in the European energy market. These changes are based on the Third Energy Package, which continues the liberalization process that began in the 1990s. With the goal of a single competitive, open energy market in the European Union, this legislative package is building a new architecture for the EU's gas market. It sets up the legal basis for network codes and the Gas Target Model, which are being actively developed and implemented. These instruments introduce fundamental changes. The long-term contract system is being transformed and price-setting principles are changing toward gas trading via hubs. National borders are blurring with countries gradually combined in market zones, which threatens the system of bilateral agreements. Network codes are being developed to overcome cross-border barriers. New rules are being proposed for implementing large infrastructure projects. The main innovations in the European gas market are summarized in Table 1.

According to its current energy policy, the EU aims to increase competition and smooth price differences among countries. Measures include a gradual transfer to "gas-gas" competition and the development of short-term trading at gas hubs. The trading system is moving from national markets to unified market zones that do not correspond to national borders, with a liquid hub in each zone. Gas transmission networks are also being unbundled from other activities of vertically integrated companies and a single European platform and regional platforms are being set up to reserve capacity. Network codes are being developed and implemented. The system of free trade and gas flows provides for a range of excess and reversible capacity for transportation. The scale and complexity of these changes are such that they require permanent

\footnotetext{
${ }^{1}$ Bentek data.
} 
regulation, which calls for increased decision-making authority for the European Agency for the Cooperation of Energy Regulators (ACER) and national regulators.

Another European energy priority is the active support of energy-saving measures. According to the World Energy Council, the energy intensity of the European economy fell from 0.087 per koe $/ \$ 05$ p in 2000 to $0.067 \mathrm{koe} / \$ 05$ p in 2014 , or by $31 \%$. This impressive change was due to both the transformation of the economy itself, including closing energy-intensive capacities, and the implementation of energy-saving measures. Target was to reduce energy consumption by $20 \%$ from the calculated level without implementing relevant measures by 2020 and by $27 \%$ by 2030 .

As of 2015, the trajectory of changes in consumption suggests that the EU will meet the planned level by 2020 . However, that will be only partially linked to the success of energy-saving measures. Around a third of the targeted reduction in energy consumption will come from the fact that economic growth in region is lower than expected.

Measures regarding renewable energy sources and reduced overall energy consumption will allow the EU to meet another important target in its current energy policy - enforcement energy security by reducing dependence on external energy resources.

Table 1: The European Union's Gas Market: Key Directions for Development

\begin{tabular}{|c|c|c|c|}
\hline & $\begin{array}{c}\text { The situation at the juncture } \\
\text { of the 20th and the 21st } \\
\text { centuries }\end{array}$ & The current situation (2015) & Development plans \\
\hline Competition & $\begin{array}{l}\text { Limited competition and } \\
\text { number of suppliers; market } \\
\text { concentration is high }\end{array}$ & $\begin{array}{l}\text { Insubstantial increase in } \\
\text { competition; the number of } \\
\text { suppliers is growing mainly due } \\
\text { to liquified natural gas (LNG); } \\
\text { market concentration remains } \\
\text { high }\end{array}$ & $\begin{array}{l}\text { High competition; deconcentrated } \\
\text { market }\end{array}$ \\
\hline Market borders & $\begin{array}{l}\text { Separate national markets: } \\
\text { bilateral intergovernmental } \\
\text { agreements / large } \\
\text { consumers and suppliers }\end{array}$ & $\begin{array}{l}\text { National markets and } \\
\text { considerable differences } \\
\text { between the countries remain. } \\
\text { Cross-country zones set up } \\
\text { as pilot projects; integration } \\
\text { processes are developing; } \\
\text { less pronounced national } \\
\text { sovereignty gas-related } \\
\text { dispute resolution (deliveries, } \\
\text { infrastructure) }\end{array}$ & $\begin{array}{l}\text { Market zones (untied to national } \\
\text { markets); blurred national borders } \\
\text { and cross-border barriers; deep } \\
\text { market integration; likely increase } \\
\text { of alliances with third parties, } \\
\text { including non-market solutions }\end{array}$ \\
\hline Price differences & $\begin{array}{l}\text { Countries highly differ in } \\
\text { terms of wholesale and retail } \\
\text { prices }\end{array}$ & $\begin{array}{l}\text { Price differentiation remains, } \\
\text { but there is a tendency toward } \\
\text { price convergence at the hubs, } \\
\text { primarily in western Europe }\end{array}$ & $\begin{array}{l}\text { A smoothing of price differences } \\
\text { among various market zones, } \\
\text { formation of a "fair price" }\end{array}$ \\
\hline Contracts & $\begin{array}{l}\text { Long-term contracts } \\
\text { dominate (linked to oil } \\
\text { prices) }\end{array}$ & $\begin{array}{l}\text { Hybrid model with } \\
\text { simultaneous presence of } \\
\text { long-term oil-linked contracts } \\
\text { and deliveries with hybrid price } \\
\text { formula; reduced contract } \\
\text { lengths }\end{array}$ & $\begin{array}{l}\text { A movement toward short-term } \\
\text { trading based on "gas-gas" } \\
\text { competition }\end{array}$ \\
\hline Hubs & $\begin{array}{l}\text { Start of gas trading via hubs, } \\
\text { with a small number of } \\
\text { traders }\end{array}$ & $\begin{array}{l}\text { Total number of hubs created } \\
\text { (18, including } 9 \text { main ones); } \\
\text { hub-based gas trading leaning } \\
\text { toward northwestern Europe; } \\
\text { low gas hub liquidity }\end{array}$ & $\begin{array}{l}\text { A liquid hub in each market zone, } \\
\text { with a large number of suppliers } \\
\text { and traders }\end{array}$ \\
\hline
\end{tabular}




\begin{tabular}{|l|l|l|l|}
\hline Infrastructure & $\begin{array}{l}\text { The situation at the juncture } \\
\text { of the 20th and the 21st } \\
\text { centuries }\end{array}$ & The current situation (2015) & \multicolumn{1}{|c|}{ Development plans } \\
\hline $\begin{array}{l}\text { Used mainly by vertically } \\
\text { integrated companies } \\
\text { (often on a monopoly } \\
\text { basis); limited third-party } \\
\text { access; insufficient overall } \\
\text { infrastructure with no } \\
\text { reverse deliveries }\end{array}$ & $\begin{array}{l}\text { Gas-transmission networks } \\
\text { unbundled from vertically } \\
\text { integrated companies. Pilot } \\
\text { implementation of booking } \\
\text { network capacities on market } \\
\text { terms; third-party access. } \\
\text { Investment signals towards } \\
\text { the expansion of capacities } \\
\text { have not developed. Reverse } \\
\text { deliveries }\end{array}$ & $\begin{array}{l}\text { Full launch of all-European/ } \\
\text { regional platforms for booking } \\
\text { capacities. Excess transportation } \\
\text { capacities and other infrastructure } \\
\text { (underground gas storage, LNG } \\
\text { terminals) set up; reverse flows } \\
\text { and third-party access widely } \\
\text { available. capacity constructed for } \\
\text { external deliveries only given clear } \\
\text { investment signals }\end{array}$ \\
\hline Regulators & $\begin{array}{l}\text { Insignificant role of national } \\
\text { regulators }\end{array}$ & $\begin{array}{l}\text { Strengthened role of national } \\
\text { and European regulators }\end{array}$ & $\begin{array}{l}\text { Further strengthened role of ACER } \\
\text { and national regulators }\end{array}$ \\
\hline Network codes & $\begin{array}{l}\text { Absent network codes; high } \\
\text { cross-border costs }\end{array}$ & $\begin{array}{l}\text { Development and pilot } \\
\text { implementation of network } \\
\text { codes for free gas flows and } \\
\text { reduced transaction costs }\end{array}$ & $\begin{array}{l}\text { Full implementation of network } \\
\text { codes; a significant reduction in } \\
\text { cross-border costs }\end{array}$ \\
\hline
\end{tabular}

Note: ACER $=$ European Agency for the Cooperation of Energy Regulators.

Source: Kulagin, Mitrova [2015].

\section{EU Regulatory Initiatives in 2014-2015 and Their Impact on Russia's Interests}

In the process of energy market liberalization, the region's growing dependence on imports and the energy sector's movement toward decarbonization, the EU's energy priorities are changing fundamentally. These changes are reflected in the development of new initiatives and their implementation as regulations. Many new documents directly or indirectly, to a greater or a lesser extent, touch upon Russia's interests in a key energy market and affect existing relationships. There were several such strategic and regulatory initiatives in 2014-15.

The European Commission [2014c] presented its new climate and energy programme at the start of 2014. The programme extends the targets for renewable energy sources, carbon emissions and energy efficiency from 2020 to 2030.

The same approach was used in the communication on energy efficiency published in July 2014 [European Commission, 2014a]. This document states that if the energy efficiency indicator increases by $1 \%$, gas imports to the EU will fall by $2.6 \%$, thus reducing the EU's dependence on external energy sources. Overall, the policy on energy efficiency and energy saving is one of the most effective mechanisms to reduce overall energy consumption and is likely to produce the largest reduction in gas consumption.

In May 2014 the European Commission presented the new European Energy Security Strategy [European Commission, 2014b]. It identified dependence on import supplies as a key energy security issue. The strategy includes an analysis of the dependence of individual countries on Russian gas. It includes short-term measures to improve energy security such as increasing the capacity of underground gas storage facilities, developing infrastructure including reverse flows, reducing energy consumption and switching to alternative fuels. It also several long-term measures:

- increasing energy efficiency with an emphasis on the energy efficiency of buildings and industrial facilities; 
- increasing energy production in the EU (including renewable energy sources, fossil fuel extraction and nuclear energy) combined with the diversification of both energy resources and delivery routes;

- developing competition in the internal EU energy market with subsequent infrastructure development to increase the flexibility of flows;

- engaging in dialogue with external suppliers in a "single European voice" and informing one another before reviewing or signing any third-party agreements that could affect the security of EU energy supplies;

- developing cooperation and overcoming infrastructure limitations in order to reduce risks at both the regional and the European levels.

The European Commission's [2015] Energy Union strategy, announced in February 2015, is receiving the full attention of the European governments. This strategy has created uncertainty about any prospective energy cooperation between Russia and the EU. Even according to initial assessments, it is one of the most significant initiatives to regulate the EU energy market since the adoption of the Third Energy Package. It involves transferring a substantial amount of sovereign decision-making powers to the European Commission, including cooperation with third parties. The Energy Union strategy involves:

- strategic cooperation with Algeria, Turkey, Azerbaijan, Turkmenistan, the Middle East and Africa (with no mention of Russia as a strategic partner), including a memorandum to construct the Trans-Caspian gas pipeline between Turkmenistan and Azerbaijan;

- informing the European Commission of any energy-related intergovernmental agreements between EU members and third parties at an early stage;

- changing regulations to require gas companies to publish the terms of major purchasing contracts including prices, volume and delivery;

- accelerating the implementation of the Third Energy Package and extending the authority of ACER and national regulators;

In February 2016 the European Commission launched its landmark security of gas supply package. It released new proposals for a raft of measures that will shore up the prevention of gas crises and ensure better coordination and support among EU countries in any disruption of supply [European Commission, 2016c].

The European Commission [2016b] has also published a proposal to tighten up intergovernmental energy agreements between EU country and non-EU countries. The new rules will allow it to take action before such agreements are signed if it assesses that such an agreement could affect the security of gas supplies in another EU country or hamper the functioning of the EU's energy market.

The European Commission has outlined how to improve access to a rapidly developing global market for liquified natural gas (LNG) and improve gas storage across the EU. This would allow EU countries that depend on very few gas suppliers to diversify their supply and hence strengthen their energy security [European Commission, 2016a].

This process of updating the regulation led to a discussion about aligning existing bilateral agreements related to long-term Russian gas deliveries with EU legislation. A possible change in the standard of security of gas supply can also affect the current relationships between the parties. Relations are further affected by the development of reverse gas deliveries, which support free gas flows. Therefore, several new challenges and uncertainties arise with regard to Russian gas deliveries to Europe. This situation is exacerbated by an anti-trust investigation of Gazprom, with the EU accusing Gazprom of misusing its position in the eastern European markets. There is also a lack of clarity about using gas pipelines to their full capacity, including the OPAL pipeline project and other new projects. 
It is also necessary to emphasize the active process to extend the legislative enforcement of the Third Energy Package's requirements to the Energy Community countries, which has included Ukraine since 2012. If Ukraine meets the European requirements on unbundling transmission networks, sharing information publicly and setting up reverse flow routes, it could lead to a review of export gas flows from Russia through Ukraine and affect cooperation on gas deliveries to Ukraine.

The EU's persistency and consistency in implementing its priorities to develop the energy sector, despite resistance from some EU members, testifies to the fact that these changes are irreversible and long term.

Positive signals about cooperation between Russia and European consumers include agreements to construct the third and fourth lines of the North Stream gas pipeline to continental Europe. Large European companies will participate in this project. Another positive signal is the fact that mutually acceptable decisions to overcome the limitations of the Third Energy Package are beginning to take shape regarding large infrastructure projects, including those with Russia's participation.

A decrease in 2015 natural gas prices delivered under long-term oil-linked contracts has increased European consumer interest in Russian gas and nearly eliminated the gap between contract prices and hub/gas exchange prices. Initiatives to transform the pricing system in the market and accelerate the diversification of supply sources have thus become less relevant.

\section{A Reassessment of Projected European Gas Demand}

Various factors that determine the current and projected development of the European gas market suggest a consistent downward trend. In the last decade research organizations have been adjusting their projections of European gas demand by 2025 downward by about $250 \mathrm{bcm}$. Research done at the Energy Research Institute at the Russian Academy of Sciences (ERI RAS) and the Energy Institute at the National Research University Higher School of Economics shows that European demand is no longer growing rapidly [Kulagin and Mitrova, 2015]. Given reduced demand, even the stabilization of gas consumption at current levels with a gradual increase in some sectors (such as electricity and transport) would be considered a favourable scenario.

The main hopes for restoring demand for gas in the power generation sector, in the context of increased electric power demand and decommissioned nuclear power plants, are linked to measures to limit coal-powered generation. These measures include building an effective payment system for carbon emissions and closing old coal power plants under the Large Combustive Plant Directive and the new Industrial Emissions Directive [European Parliament and Council of the European Union, 2001, 2010]. As a result, the European power sector could become a leader in gas consumption by 2025 if gas consumption by households, the commercial sector and the industrial sector is reduced (see Figure 1). In the long term, households and the commercial sector prefer electricity as the most convenient energy source. Gas consumption in the European industrial sector will likely increase temporarily as the economy continues to recover from the 2008 global financial crisis and industrial growth takes place. Gas consumption could increase up to $7 \%$, although the overall trend of reduced industrial demand will continue. The transport sector is projected to see the fastest consumption growth. However, in absolute terms gas consumption will remain relatively low - it is projected that the current $2 \mathrm{bcm}$ will go up to $6 \mathrm{bcm}$ by 2025 in the car and marine transportation sectors. This increase will be partially due to new emissions requirements for ships in the Baltic Sea.

Therefore, in the medium term, natural gas will face tough competition in the European market, primarily in the power sector. 


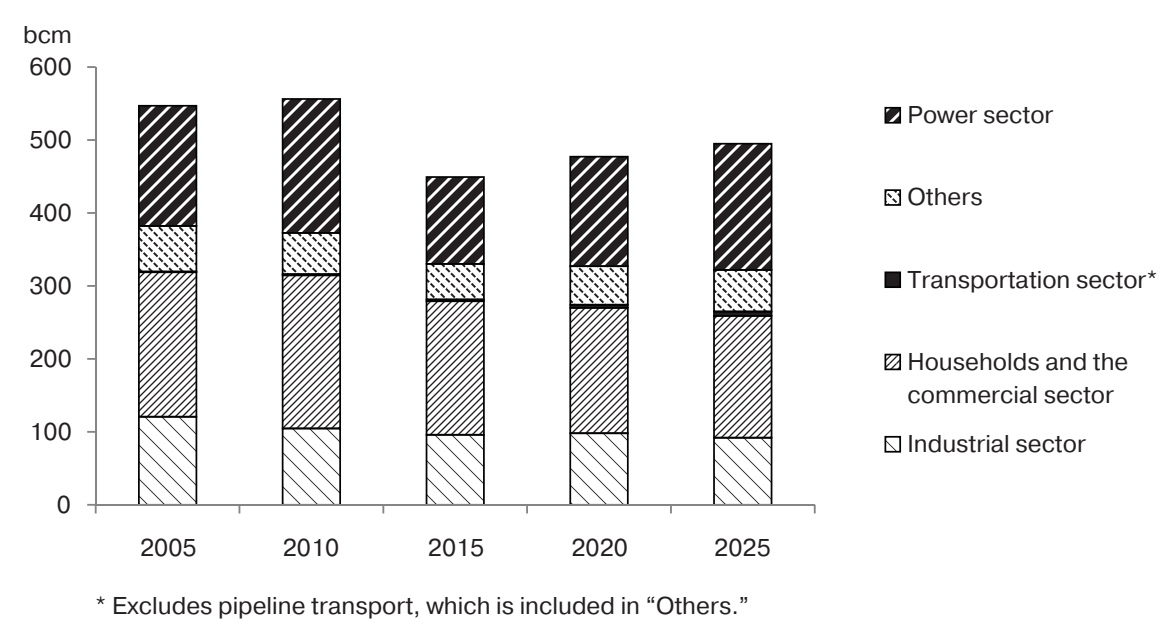

Figure 1: The Structure of Gas Consumption in Europe, by Sector

Sources: Estimates by the Energy Institute at the Higher School of Economics and Energy Research institute at the Russian Academy of Sciences, using the SCANER modelling and simulation complex (see [Makarov, Mitrova, Kulagin et al., 2011]), who analyze the gas market in 41 European countries.

\section{The Impact of Policy and Regulation on Russia's Position in the Gas Market}

During the Soviet years, a system of relationships developed in the gas market between the USSR and the European consumers. It was part of integrated cooperation between these countries. The leaders' decisions allowed the USSR to sign extensive contracts that then laid the basis for the construction of large-scale pipeline networks and gas deliveries for many decades ahead.

Russia has been exporting substantial volumes of gas to Europe for around 50 years. Until recently, no one doubted the reliability of the supply or the mutually profitable cooperation. However, transit and geopolitical issues in the 21st century have gradually politicized the gas relationship and taken it beyond a purely commercial partnership.

At the same time, European integration continues, producing new approaches to regulation and taking the gas industry beyond national jurisdictions. These factors also completely change the foundation for further partnership. Indeed, the shape of this new cooperation is not yet clear.

European gas trade involving direct bilateral contracts with guaranteed prices and volumes is increasingly losing out to short-term transactions with buyers unknown at the time of trading. The European Commission plans to control the terms of long-term contracts, so there is no link between price and delivery terms and other elements of cooperation.

The requirement to provide third-party access to gas pipelines, stipulated in the Third Energy Package, has a substantial impact on Russian-European cooperation. According to this legislation, only $50 \%$ of capacity can be used freely, and the use of the remainder must be agreed as an exception with the European Commission.

However, it is not always possible to get such permission for projects with Russia's participation. There have been several situations of projects approved by national authorities and regulators failing to get approval by the European Commission. 
Nonetheless, there are some positive aspects. It is now possible to use existing transportation capacities to deliver Russian gas. This does not depend on the ownership of facilities, so delivery routes can vary. According to the Third Energy Package, obligations to develop infrastructure are transferred to the network operator (rather than the vertically integrated gas supplier as in the past) [European Parliament and Council of the European Union, 2009]. The operator sets up and develops the necessary infrastructure based on expected demand and deliveries. In practice this eliminates the need for massive investment from producers to build gas transportation capacity in Europe. In practical terms, however, implementation remains uncertain, especially given the lack of clarity over large transportation projects.

Gazprom's participation in short-term trade enables it to increase sales and earnings, although much depends on the market situation and the transformation in long-term contract terms.

Gas deliveries from Russia are gradually adapting to changing market conditions and requirements. Buyers are given discounts and there is partial spot-price indexation. The take-orpay approach is changing, in part thanks to deferred obligations.

If price formulas from before the global financial crisis had remained the same, the average weighted price of Russian gas delivered to Europe in 2014 would have been $25 \%$ higher than the actual price sold by Gazprom to the region. In 2015 Gazprom held a pilot auction where European suppliers could purchase gas for the winter 2015-16 and have it delivered to various points in Europe. Gazprom will continue to hold such auctions in the future.

The judgements of commercial courts on gas deliveries involving European buyers and Qatar, Algeria, Norway and Russia in 2012-13 are one reason for the changes in contract terms and prices. These judgements were mainly made in favour of the buyers. They forced the suppliers to make concessions, as well as motivated them to resolve disagreements before matters went to court.

At the end of the 20th century and the beginning of the 21st century, Russian companies, observing the experience of the top world energy companies, sought to establish production chains that maximized business effectiveness in external markets. In the gas market, such a chain involved transportation after crossing the Russian border (including establishing pipeline capacities), storage, sales to end consumers, and even the purchase and ownership of assets in further gas utilization, including power generation. In terms of profitability, this model is preferable to separate business activities, because it minimizes costs and provides stable, guaranteed sales. However, from the point of view of the European regulators, vertical integration inhibits competition and free trade.

As a result, the EU adopted legislation to prevent production and sales chains created and owned by a single company. Every type of business in Europe thus must be considered separately, which substantially reduces the market's attractiveness to Russian companies and narrows their interests to simple deliveries with limited participation in storage and transportation (often restricted by assets they already own). The European Commission becomes a third party to signing and implementing contracts that been historically been bilateral. The European Commission intends to control and approve various aspects of cooperation.

Political complications between Russia and the EU have led to tougher political statements in respect to gas cooperation. One goal of EU energy policy is reduced dependence on Russian gas, and disruptions in Russian gas supplies are among the most debated crisis scenarios. Given excess gas supply and low demand, the current atmosphere threatens not only the growth of Russian gas imports to Europe, but also the prolongation of existing contracts once they reach the end of their term. Indeed, even retaining already signed contracts could be at risk in the most negative scenarios. 


\section{Imports to Europe and Russia's Competitive Ability}

This article analyzes the European regional gas balance and potential exports by gas-producing countries to assess the import situation with Europe, the potential for change and the level of competition. In 2006, growth in European demand for gas began to stagnate and then declined sharply (see Figure 2). Given many factors influencing the state of the market in the medium and long term, there is a consensus among experts about further demand dynamics in Europe. According to ERI RAS assessments, there is some basis for growth to recover, although it is unlikely that the peak demand recorded in 2010 would ever be achieved again.

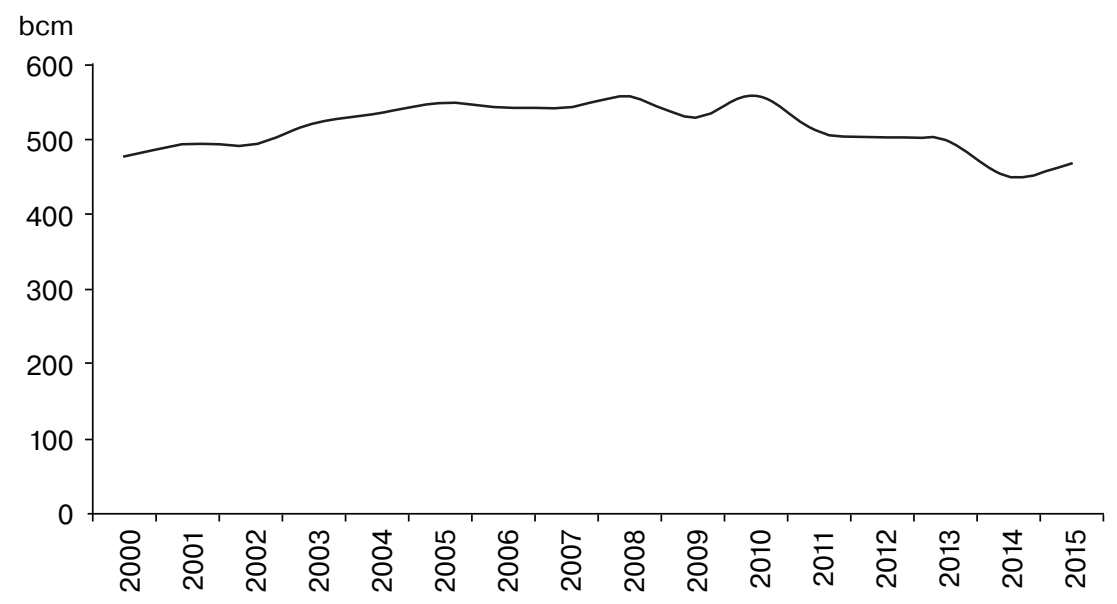

Figure 2: Gas Consumption in Europe, 2000-2015

Sources: International Energy Agency [2015a].

At the same time that demand fell in 2005-14, gas production in Europe decreased by nearly $20 \%$. The slump was recorded in the United Kingdom, Germany, Italy and Denmark. Limitations on gas production were enforced in the Netherlands because of potential earthquakes. For the decade beginning 2015, internal gas production in Europe is expected to fall at a slower rate, to around $200 \mathrm{bcm}$ by 2025 (see Figure 3).

Between 2010 and 2015, Algeria, a main pipeline supplier, cut deliveries to Europe, because of insufficient volumes of gas for export. Norway gradually increased delivery, and Russia showed a varied dynamics (see Figure 4). At the same time, LNG exports fell sharply, although the global LNG trade stabilized temporarily and supplies were redirected to the Asian market.

European demand is expected to grow moderately from $450 \mathrm{bcm}$ in 2015 to $495 \mathrm{bcm}$ in 2025, with import demand expected to rise from $210 \mathrm{bcm}$ to $295 \mathrm{bcm}$. Europe's import needs for 2015 were almost entirely met by minimum contracted gas deliveries. Uncontracted opportunities are not likely to appear before 2020. A significant number of long-term contracts will expire by 2025 , and some of these volumes will probably be replaced by short-term trade.

To assess the possibility of higher volumes of gas exported to Europe than to other regions, exports were calculated for all routes in the basic scenario except for Europe. Free potential gas exports will total around $450 \mathrm{bcm}$, which is 1.5 -fold greater than European gas demand (see Figure 5). More than $220 \mathrm{bcm}$ is estimated to come from Russia (provided transit through Ukraine is possible). Delivery to Europe will substantially increase from North America (by 
$60 \mathrm{bcm}$ ) and the Middle East and the Caspian region (by $42 \mathrm{bcm}$ ). Europe's potential for diversified imports will thus increase significantly.

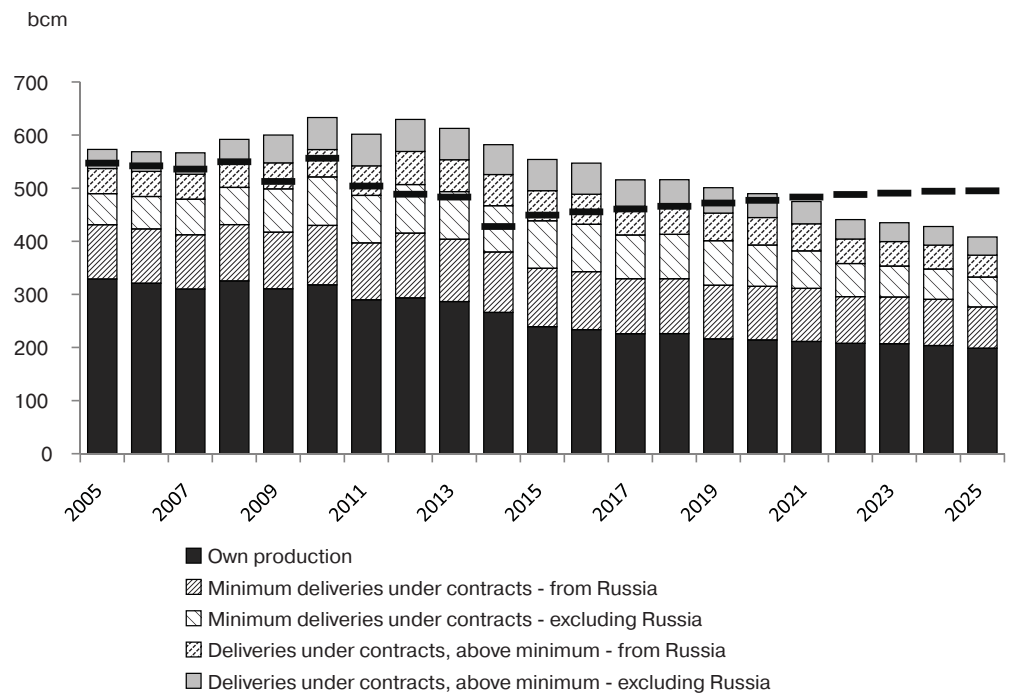

Figure 3: Projected European Gas Balance, 2005-2025

Note: $\mathrm{bcm}=$ billion cubic metres.

Source: International Energy Agency [2015b], Energy Research Institute at the Russian Academy of Sciences.

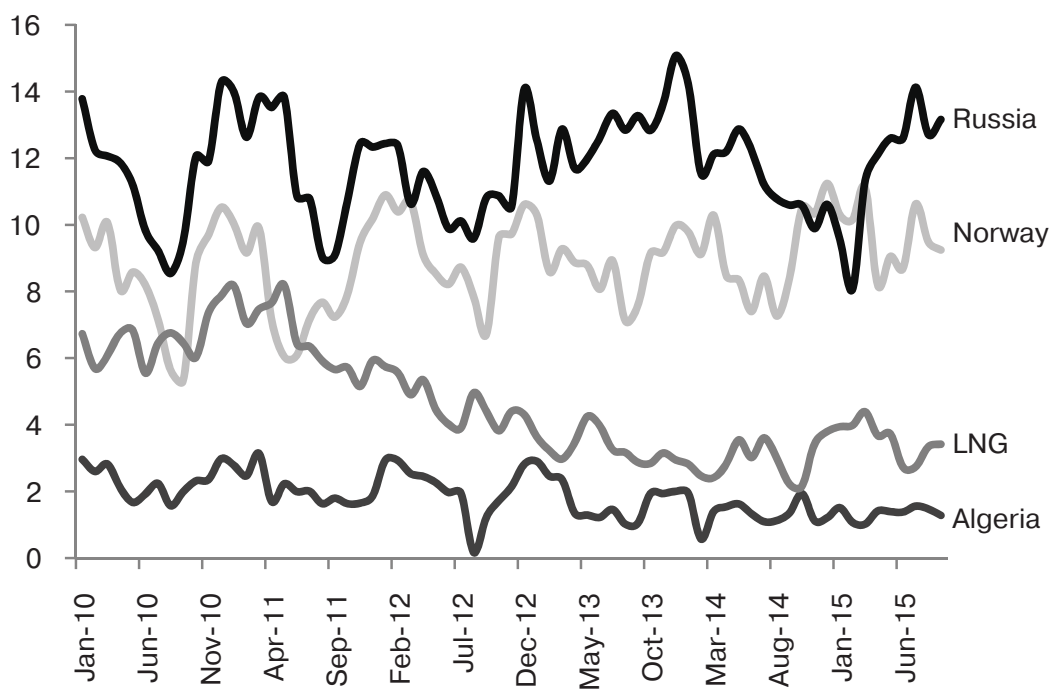

Figure 4: Physical Gas Flows to Europe

Note: $\mathrm{bcm}=$ billion cubic metres; $\mathrm{LNG}=$ liquified natural gas.

Source: International Energy Agency [2015b]. 


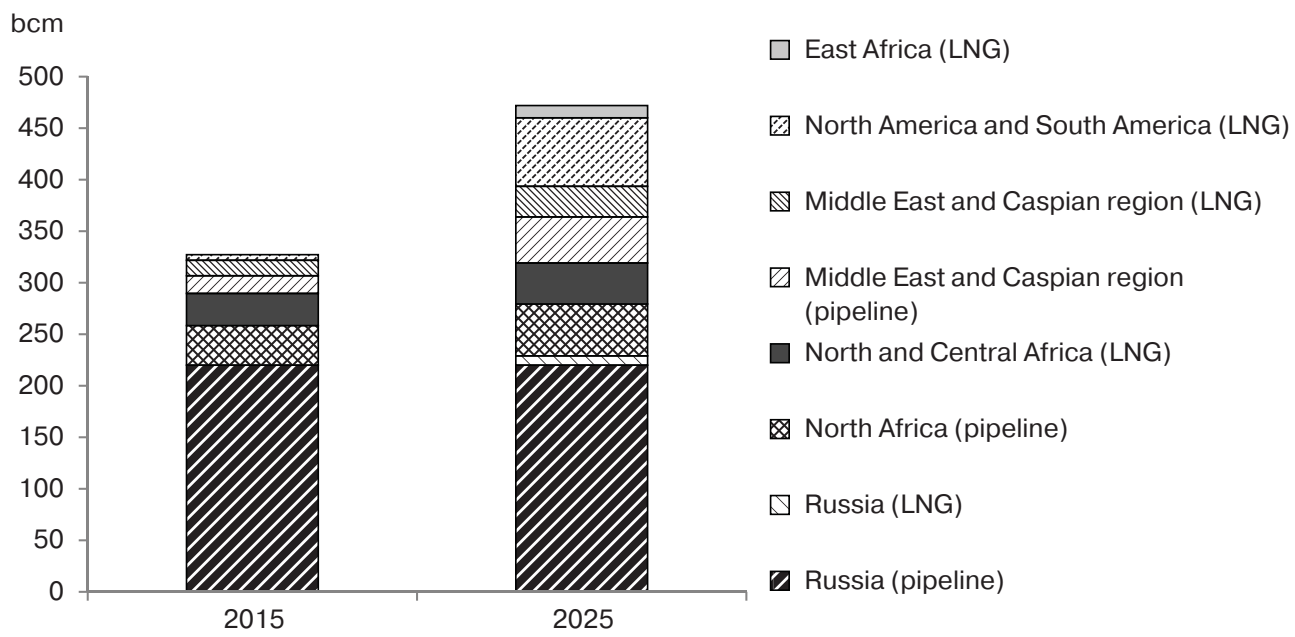

Figure 5: Potential Gas Imports to Europe, by Supplier

Note: $\mathrm{bcm}=$ billion cubic metres; $\mathrm{LNG}=$ liquified natural gas.

Source: Assessments made by the Energy Institute at the Higher School of Economics and the Energy Research Institute at the Russian Academy of Sciences.

There is now significantly greater potential for LNG deliveries, given the presence of infrastructure and supplier capacity (see Figure 6).

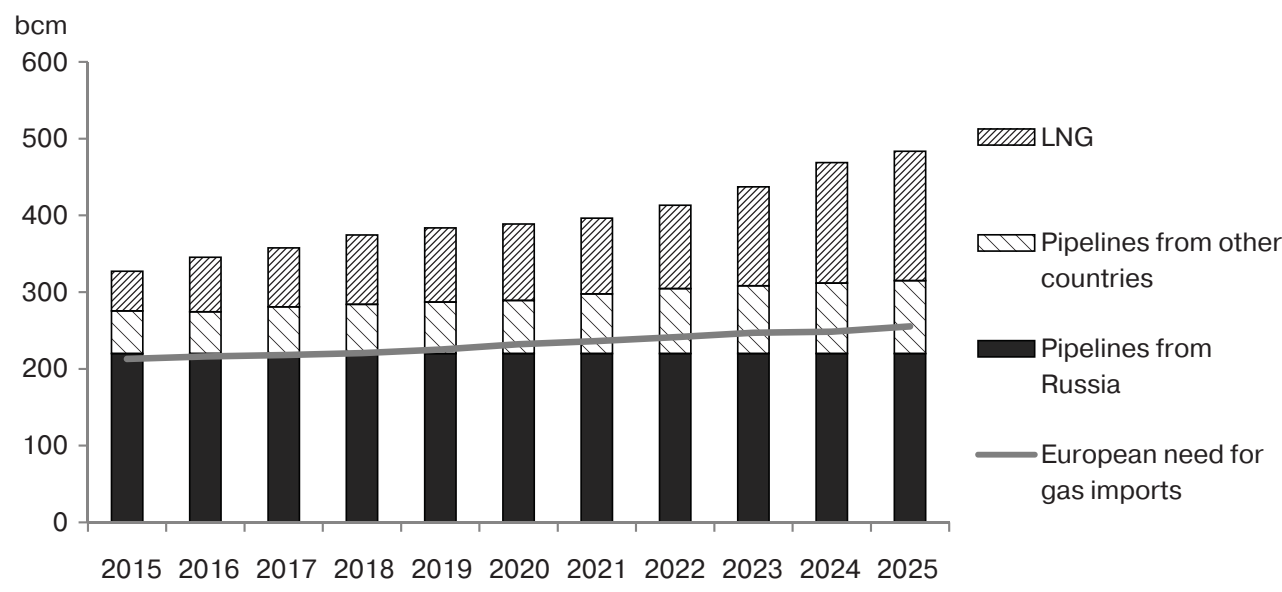

Figure 6: Potential for Pipeline and Liquified Natural Gas Imports to Europe

Note: $\mathrm{bcm}=$ billion cubic metres; $\mathrm{LNG}=$ liquified natural gas.

Sources: Energy Institute at the Higher School of Economics and Energy Research Institute at the Russian Academy of Sciences.

Changes in expected gas demand in Europe have eliminated the need for large volumes of potential supply, compared to earlier expectations. This includes around $50 \%$ of potential supplies from Russia. These changes have also led to a significant reduction in projected final prices (see Figure 7). 


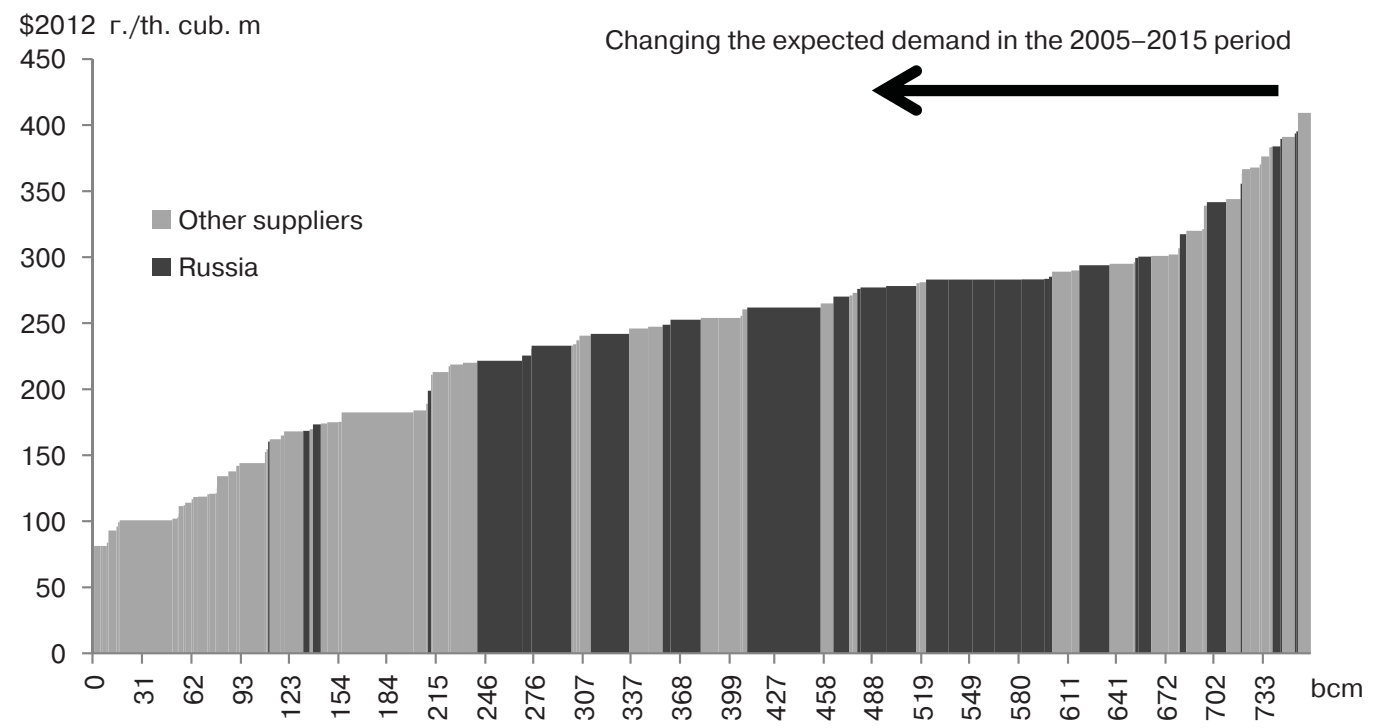

Figure 7: Gas Supply Curve in Europe in 2025

Note: $\mathrm{mcm}=$ thousand cubic metres; $\mathrm{bcm}=$ billion cubic metres. Based on an analysis of potential gas supply in Europe, taking into account internal production and excluding exports. Gas demand is based on estimates by the International Energy Agency, 2005 and 2014.

Source: Viatcheslav Kulagin and Tatiana Mitrova [2015].

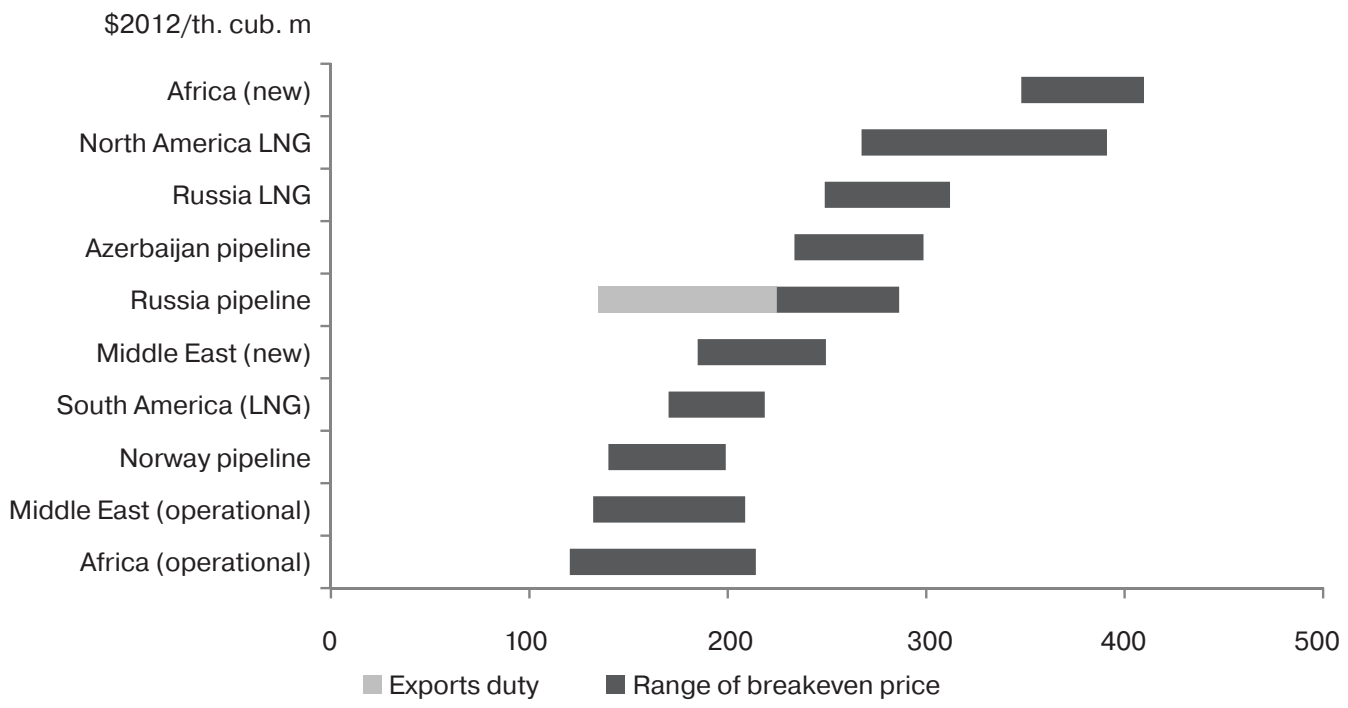

Figure 8: Break-Even Price Ranges for Gas Supplies to Western Europe in 2025

Note: $\mathrm{mcm}=$ thousand cubic metres; $\mathrm{LNG}=$ liquified natural gas.

Source: Estimates by the Energy Institute at the Higher School of Economics and Energy Research Institute at the Russian Academy of Sciences. 
The competitiveness of available gas supply differs considerably, depending on the specific delivery points in Europe. It is determined by total gas delivery costs. Russian gas is significantly different in terms of estimated costs: the level of export duty depends on the sale price. Currency is also a factor, as most costs in Russia are incurred in roubles. In 2014-15, as the rouble weakened substantially against the U.S. dollar and the euro, production and transportation costs in Russia fell, as expressed in hard currency. This improved the competitive ability of Russian oil and gas products in external markets and lowered the break-even point for production and delivery.

Among the new suppliers to western Europe, Russian gas is second only to gas from the Middle East in terms of competitive ability (see Figure 8). The most expensive deliveries to this region are from the United States, Canada, Mozambique and Tanzania. Russian gas is more competitive in central and eastern Europe because Russian transportation costs are lower and costs are increased for other suppliers.

\section{Changing Market Conditions}

The prospects for the European gas market depend on several factors: demand, supply possibilities, price and contract terms for deliveries. Companies and states must consider the most likely scenarios and evaluate market sensitivities in order to be able to plan.

Using a basic scenario and economic and mathematical modelling (simulation) tools, this article assesses market stability in various situations and the consequences for Russian gas deliveries and export revenues.

\section{The Basic Scenario}

The basic scenario assumes that after 2015 gas demand in Europe will resume growing by $0.1 \%$ per annum until 2025 and internal production will continue to decrease (see Figure 3). Increased imports will come mainly from Africa, the Middle East and the Caspian region. Approximately $15 \mathrm{bcm}$ of LNG will be delivered to Europe from North America. The volume of gas exports from Russia will stabilize (see Figure 9).

As of 2016, European gas spot prices will gradually reach around \$308 in 2012 U.S. dollars per thousand cubic metres $(\mathrm{mcm})$ in 2012 dollars by 2025. The difference with the oil-linked gas prices will be around $\$ 50-70 / \mathrm{mcm}$ in 2012 dollars.

\section{Key Factors}

To assess the sensitivity of the European gas market to key changes, the following factors have been assessed: measures to improve energy efficiency and to promote the use of renewable energy sources, low demand in Asia, high production in the Middle East, and accelerated European and global economic growth.

Measures to promote energy efficiency and the use of renewables would prompt a $12 \%$ decrease in gas consumption in Europe from the basic scenario by 2025. Competition among suppliers would grow and, as a result, deliveries from all regions would decrease. However, this decrease is more relevant for the LNG imports, which are redistributed in the global market. An excess in supply would lead to a price reduction of $\$ 16 / \mathrm{mcm}$ (see Table 2).

Low demand in Asia would also lead to excess supply. However, in this case LNG volumes delivered to Europe would increase due to the volumes not required in Asia. Therefore, the countries supplying Asia would partially reduce production and reorient toward other markets. Additional LNG arriving in Europe would mainly displace Russian deliveries. Demand would grow by $3 \mathrm{bcm}$ due to lower prices. 


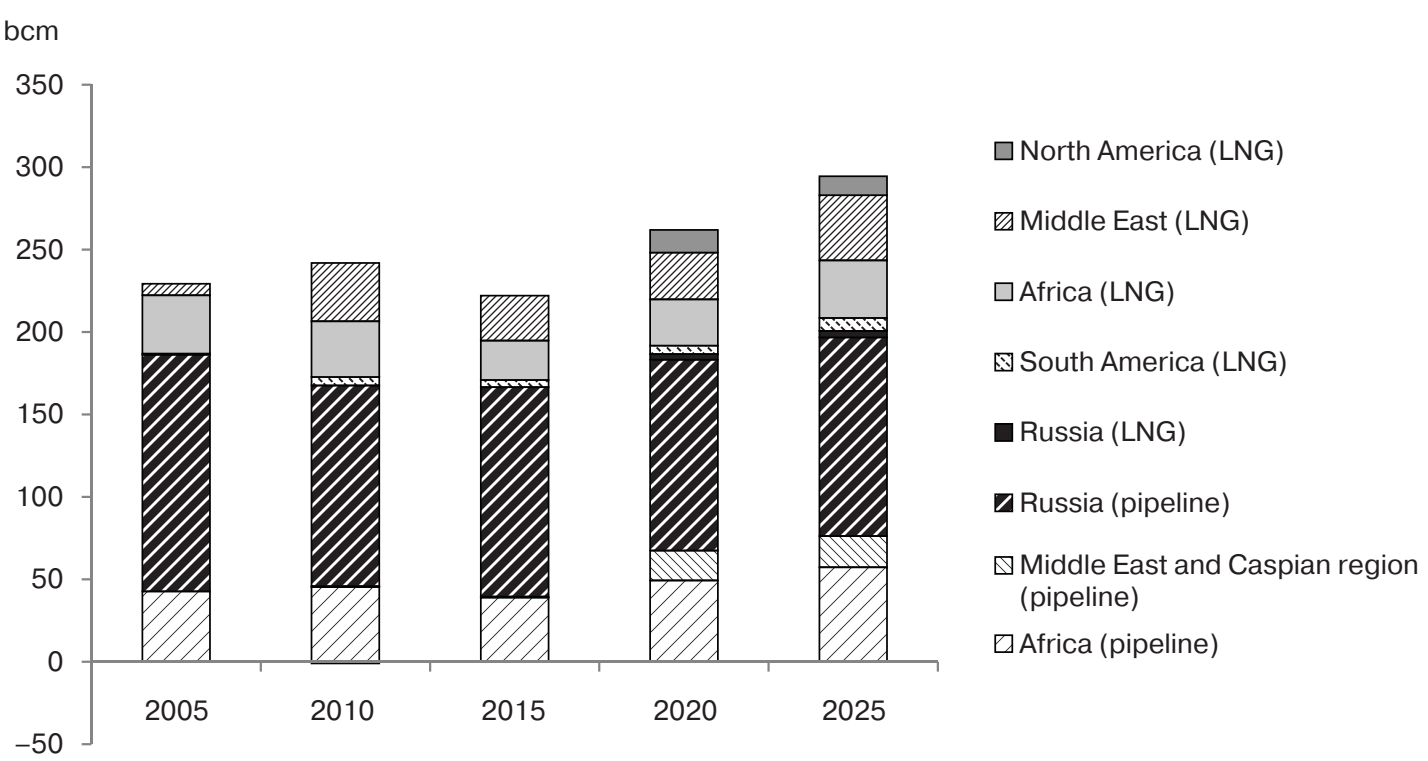

Figure 9: Gas Imports to Europe (Basic Scenario)

Note: $\mathrm{bcm}=$ billion cubic metres; $\mathrm{LNG}=$ liquified natural gas.

Sources: International Energy Agency [2014], Energy Research Institute at the Russian Academy of Sciences, the Energy Institute at the Higher School of Economics.

Table 2: Main Indicators in the European Gas Market (Europe 41) as of 2025

\begin{tabular}{|l|c|c|c|c|c|}
\hline & $\begin{array}{c}\text { Consumption, } \\
\text { bcm }\end{array}$ & $\begin{array}{c}\text { Spot prices, } \\
\text { U.S. dollar } \\
\text { /mcm }\end{array}$ & $\begin{array}{c}\text { Imports from } \\
\text { Russia, bcm }\end{array}$ & $\begin{array}{c}\text { Imports from the } \\
\text { Middle East, Africa } \\
\text { and the Caspian } \\
\text { region, bcm }\end{array}$ & $\begin{array}{c}\text { Imports from } \\
\text { the United } \\
\text { States, bcm }\end{array}$ \\
\hline $\mathbf{2 0 1 0}$ indicators & 556 & 261 & 122 & 115 & 0 \\
\hline $\mathbf{2 0 1 4}$ indicators & 428 & 290 & 123 & 67 & 0 \\
\hline Basic scenario & 495 & 308 & 124 & 151 & 12 \\
\hline $\begin{array}{l}\text { Measures to promote } \\
\text { energy efficiency and } \\
\text { renewable energy sources }\end{array}$ & 438 & 292 & 109 & 117 & 6 \\
\hline Low demand in Asia & 498 & 286 & 107 & 166 & 17 \\
\hline $\begin{array}{l}\text { Increased production } \\
\text { in the Middle East }\end{array}$ & 496 & 297 & 111 & 168 & 9 \\
\hline $\begin{array}{l}\text { Accelerated European } \\
\text { and global economic } \\
\text { growth }\end{array}$ & 508 & 356 & 144 & 129 & 28 \\
\hline
\end{tabular}

Note $: \mathrm{bcm}=$ billion cubic metres; $\mathrm{mcm}=$ thousand cubic metres.

Sources: Estimates by the Energy Institute at the Higher School of Economics and Energy Research Institute at the Russian Academy of Sciences. 
Growing gas production in the Middle East would lead to more deliveries from this region both to Europe and Asia. This would displace more expensive gas from other producers. Russian deliveries to Europe would fall by $13 \mathrm{bcm}$. Increased deliveries from the Middle East would have a relatively modest impact on the market because the projected period has a small range (based on the investment cycles necessary to implement new projects). In the long term, the region has the potential for a more substantial increase in gas production and export infrastructure.

Accelerated growth in the European and global economies would create the most favourable conditions for gas exporters. Demand, prices and import volumes would grow. However, the import structure would change. Gas from the Middle East and Africa would partially be routed to Asia. Here demand growth would be more significant, supported by sales logistics that makes it easy to redirect deliveries. The niche freed up in Europe would be filled by deliveries from Russia and North America.

\section{Possible Pricing Changes for Russian Gas in Europe}

The gas trade in Europe is undergoing a transformation. The spot market is actively developing. Suppliers are adapting long-term contracts to market conditions to be more competitive and to minimize the risks of court appeals against delivery terms. While some exporters partially or fully link a spot price in their contracts, others are not abandoning oil indexation but relaxing other terms. In these conditions, market strategies are important for all suppliers. To evaluate the advantages and disadvantages of Russia's export pricing policy, delivery volumes and sales prices have been calculated, using export revenues as the main criteria.

The calculations suggested a gradual recovery of oil prices beginning in 2016 up to $\$ 94$ in 2014 U.S. dollars per barrel by 2025. Gas spot prices would also grow, although at a slower pace. As a result, the highest gas price would be in the scenarios most closely linked to the oil price. However, in such cases the consumer chooses the minimum contractual obligations and refuses to prolong the contracts. As a result, delivery volumes and export revenues would be the lowest of all the scenarios.

The other extreme would be a move away from all the contracts and sales through the spot market alone. This would generate a fall in delivery volumes as clients would be lost as they purchase from other suppliers for various reasons.

The most favourable option in terms of earnings would be for Russia to retain its contracts in volume terms but bring its price as close to the market price as possible. This could be done via discounts or partial spot price indexation. Russia would make additional sales via short-term trade or auctions, which were piloted in 2015.

One of the most important issues is the term for selecting gas over minimum contractual obligations. The market functions in such a way that there is no need to select gas above the obligations when it is possible to purchase it in the short-term market. However, if this market were to become more expensive, it would be better to select additional contracted gas. Therefore volumes above the "take or pay" obligations would hold back gas spot prices in deficit conditions. They would, in fact, set the highest price and make long-term contracts the most expensive, regardless of the market situation. For this very reason, it would be helpful for suppliers to reduce the range of free selection and not aim to set concessions. 


\section{Conclusion}

It is already difficult to view the European gas market as providing high prospects for growing Russian gas exports. Fast demand growth is a thing of the past and the decline in internal production is slowing, but the number of gas suppliers and potential delivery volumes are increasing. There is more competition in the European energy market, both among gas suppliers and among fuel types. There will likely be price wars before 2025, primarily with American LNG. It is important for Russia to pursue a flexible export policy that could adapt to the market conditions.

Regulatory changes in the EU are forcing changes in market strategies. It is now difficult to build a vertically integrated chain or to implement transportation projects on a bilateral basis, without involving the European Commission. However, there is the potential for saving on the construction of new pipeline systems by demanding that the EU implement these projects under its new legislation. The European market remains a major one for Russia's gas exports. However, Russian companies and government need to work together in their cooperation with European colleagues, at both the political and economic levels. Only then will the market share be retained and Russian companies' interests be ensured.

\section{References}

Council of European Energy Regulators (2015) "Status Review of Renewable and Energy Efficiency Support Schemes in Europe in 2012 and 2013." 15 January. Brussels. http://www.ceer.eu/portal/page/portal/ EER_HOME/EER_PUBLICATIONS/CEER_PAPERS/Electricity/Tab4/C14-SDE-44-03_Status\%20 Review\%20on\%20RES\%20Support\%20Schemes_15-Jan-2015.pdf (March 2016).

European Commission (2014a) "Communication from the Commission to the European Parliament and the Council: Energy Efficiency and Its Contribution to Energy Security and the 2030 Framework for Climate and Energy Policy.” COM/2014/520 Final, Brussels, 23 July. http://eur-lex.europa.eu/legal-content/EN/ ALL/?uri=celex\%3A52014DC0015 (March 2016).

European Commission (2014b) "Communication from the Commission to the European Parliament and the Council: European Energy Security Strategy.” COM/2014/0330 Final, Brussels, 28 May. http://eur-lex. europa.eu/legal-content/EN/TXT/?uri=CELEX\%3A52014DC0330 (March 2016).

European Commission (2014c) "Communication from the Commission to the European Parliament, the Council, the European Economic and Social Committee and the Committee of the Regions: A Policy Framework for Climate and Energy in the Period from 2020 to 2030.” COM/2014/015 Final, Brussels, 22 January. http://eur-lex.europa.eu/legal-content/EN/ALL/?uri=CELEX:52014DC0015\&from=EN (March 2016).

European Commission (2015) "Communication from the Commission to the European Parliament, the Council, the European Economic and Social Committee, the Committee of the Regions and the European Investment Bank: A Framework Strategy for a Resilient Energy Union with a Forward-Looking Climate Change Policy." COM/2015/080 Final, Brussels, 25 February. http://eur-lex.europa.eu/legal-content/EN/ TXT/?uri=COM:2015:80:FIN (March 2016).

European Commission (2016a) "Communication from the Commission to the European Parliament, the Council, the European Economic and Social Committee and the Committee of the Regions on an EU Strategy for Liquefied Natural Gas and Gas Storage.” COM(2016) 49 final, Brussels, 16 February. http://eur-lex. europa.eu/legal-content/EN/TXT/?uri=COM:2015:80:FIN (March 2016).

European Commission (2016b) "Decision of the European Parliament and of the Council on Establishing an Information Exchange Mechanism with Regard to Intergovernmental 
Agreements and Non-binding Instruments between Member States and Third Countries in the Field of Energy and Repealing Decision No. 994/2012/EU.” COM(2016) 53 final, 16 February. Brussels. https://ec.europa. eu/transparency/regdoc/rep/1/2016/EN/1-2016-53-EN-F1-1.PDF (March 2016).

European Commission(2016c) "Regulation of the European Parliament and of the Council Concerning Measures to Safeguard the Security of Gas Supply and Repealing Regulation (EU) No. 994/2010." COM(2016) 52 final, Brussels, 16 February. http://eur-lex.europa.eu/legal-content/EN/TXT/?uri=CELEX\%3A52016PC0052 (March 2016).

European Parliament and Council of the European Union (2001) "Directive 2001/80/EC of the European Parliament and of the Council of 23 October 2001 on the Limitation of Emissions of Certain Pollutants into the Air from Large Combustion Plants." Official Journal of the European Communities. http://eur-lex.europa.eu/ legal-content/EN/TXT/PDF/?uri=CELEX:32001L0080\&from=EN (March 2016).

European Parliament and Council of the European Union (2009) "Directive 2009/73/EC of the European Parliament and of the Council of 13 July 2009 Concerning Common Rules for the Internal Market in Natural Gas and Repealing Directive 2003/55/EC.” Official Journal of the European Communities. http://eur-lex. europa.eu/legal-content/EN/TXT/PDF/?uri=CELEX:32009L0073\&from=EN (March 2016).

European Parliament and Council of the European Union (2010) "Directive 2010/75/EU of the European Parliament and of the Council of 24 November 2010 on Industrial Emissions (Integrated Pollution Prevention and Control)." Official Journal of the European Communities 53, pp. 17-119. http://eur-lex.europa.eu/legalcontent/EN/TXT/PDF/?uri=OJ:L:2010:334:FULL\&from=EN (March 2016).

International Energy Agency (2014) “Natural Gas Information (2014 Edition).” Paris, https://www.iea.org/ Textbase/nptoc/Gas2014TOC.pdf (March 2016).

International Energy Agency (2015a) “Natural Gas Statistics.” Paris, http://www.iea.org/statistics/topics/ naturalgas (December 2015).

International Energy Agency (2015b). "Statistics.” Paris, http://www.iea.org/statistics (December 2015).

Kulagin, Viatcheslav and Tatiana Mitrova, eds. (2015) Gazovyj rynok Evropy: utrachennye illjuzii $i$ robkie nadezhdy. [Gas Market of Europe: Lost Dreams and Shy Hopes.] Moscow: Energy Research Institute of the Russian Academy of Sciences and the National Research University Higher School of Economics.

Makarov, Alexei, Tatiana Mitrova, Viatcheslav Kulagin and Sergei Filippov (2011) SCANER: model'noinformacionnyj kompleks [SCANER: Model and Information Complex]. Moscow: Energy Research Institute of the Russian Academy of Sciences. 